\title{
ON THE PHYSICAL AND MATHEMATICAL MODELING OF THE COUPLING OF RIVERS AND AQUIFERS AS SUSTAINABLE WATER SUPPLY SYSTEMS
}

\author{
J.D. MARTÍNEZ-NÁJERA ${ }^{1}$, C. CRUICKSHANK-VILLANUEVA ${ }^{2} \&$ M. BEREZOWSKY-VERDUZCO ${ }^{2}$ \\ ${ }^{1}$ Comisión Federal de Electricidad, GEIC, Subgerencia de Estudios Hidrográficos, México. \\ ${ }^{2}$ Universidad Nacional Autónoma de México, Instituto de Ingeniería, México.
}

\begin{abstract}
A physical and mathematical model is presented to simulate realistic hydrological conditions and to evaluate coupled river and aquifer as water supply system. The approach is applied to estimate the extraction effects on the river and related aquifers under different conditions, with the purpose of determining the water supply potential and sustainability of the coupled system. The model consists of the conceptual and numerical coupling of two structures that take into account different aspects of the systems being considered. The first is a free-surface flow structure, and it carries out the balance of mass and momentum along the river course, whereas the second one is of hydrogeological type that performs the mass balance in combination with Darcy's law in each aquifer of interest for evaluation purposes. The two parts of the model are coupled by their source terms with a very simple linear relationship; the numerical implementation is carried out by using MODFLOW and ISIS codes. After calibrating the models with field parameters, an iterative coupling process is given where each structure must satisfy their criteria of internal convergence. The complete model is satisfactory whenever the iterative coupling process and the hydrogeological and hydraulic models converge. The conceptual approach is applied to the real and natural system constituted by the Papagayo river and the aquifers located in the river banks locally known as Norte, Obra de Toma, and Lomas de Chapultepec, in the State of Guerrero, México to determine their sustainable water supply potential.
\end{abstract}

Keywords: darcy's law, equations of Saint-Venant, flow balance in aquifers, stream-aquifer-coupled systems.

\section{INTRODUCTION}

There are several approaches to analyze the river and aquifer interaction. The study of the flow in aquifers and streams through physical-based analysis and numerical simulation models has been carried out in many occasions considering both systems separately. In the best situations when analyzing one of them, the other is considered in a simple and incomplete manner; yet each individual component constitutes a dynamic system that in turn interacts dynamically with the other. Each system is governed by its own field equations of balance of mass, energy, and constitutive relationships that are related among themselves by coupling terms. The purpose of this paper is to present an approach to simultaneously evaluate the behavior of rivers and aquifers as sustainable supply systems, under realistic conditions, based on their balance equations of mass and energy coupled by physical flow exchange terms. The numerical implementation is carried out by using MODFLOW and ISIS models. The combined model makes possible the evaluation of availability and sustainability of water for supply aims, when underground exploitation sites are near or on river courses; furthermore, the approximation remains valid when the wells lie far from river courses; in these case the river and aquifer interaction is less intense. One special situation arises when critical supply conditions are encountered, that is, when the aquifer evidences trends of acute drawdown or when the stream flow reaches minimum values.

The model presented incorporates the conceptual and numerical features of two structures that take into account hydrological aspects of the system in consideration. The approach is constituted by a surface and a groundwater model. The surface model is made up of the balance of mass and 
momentum in the river crossing the aquifers with which the joint potential is intended to be evaluated. The groundwater model considers the hydrogeological aspects of the aquifers related with streams as well as the exchange of water between the aquifers and rivers. The purpose of the complete model is to analyze the joint stationary and transient performance of the aquifers and rivers under natural realistic hydrological conditions and supply scenarios.

\section{PREVIOUS WORKS}

The ground and superficial waters are components of a hydrological continuum, Sophocleous [1], which interact from different topographic, geologic, biotic, and climatic aspects. The availability and contamination of one of them affect the other; the effective management and sustainability of the resource necessarily implies the knowledge of their mutual interaction mechanisms in both local and regional scales; human activities have ecological significance in such interaction. The physical and chemical interaction is variable at each sector of a basin, Nilsson et al. [2]; the key to understand and quantify the interaction of these complex processes of flow and transport of aqueous and nonaqueous substances reside in the identification of unique parameters that characterize individual sub-basins.

In Niazi [3], a similar conceptual model, based on a kinematic wave model, applies a simplified version of the Saint-Venant's equations. Their model considers the effect of the time elapsed during the simulation, because of the difference in the time residence of water in rivers and aquifers; their results suggest that time affects predictions of water exchange between both systems. Niazi [3] uses MODFLOW to simulate groundwater flow and implements the kinematic wave model in EXECEL and couples them in an iterative fashion. On the other hand, in the present work the full SaintVenant's equations are employed; therefore, the analysis of the simultaneous flow of rivers and aquifers is given in a more complete realistic scheme.

Swain and Wexler [4] have developed a general purpose code known as MODBRANCH to address the problem; their scheme is similar to this work; in addition to representing the works developed independently, CFE [5] and Martínez-Nájera et al. [6], their difference resides in the model used to simulate the flow in rivers, and in the fact that in Swain and Wexler [4] the flow exchange is estimated with a redundant approach in both aquifer and river modules. The scheme proposed in Swain and Wexler [4] is based on the BRANCH model of Schaffranek et al. [7], whereas in this work the ISIS code, Halcrow [8], is used to solve the mass and momentum balance in rivers. With the ISIS code, it is possible to simulate hydraulic structures in streams, and the code allows to model subcritical and supercritical flows with significant longitudinal and transversal topographic variations. On the other hand, the BRANCH code requires that the flow remains always in a subcritical condition, with gentle longitudinal and transversal topographic variations to ensure a flow subcritical. The inclusion of hydraulic structures in the river model is discussed in Swain [9] but not included in the BRANCH code, Schaffranek et al. [7]. In Swain and Wexler [4] as well as in this work, the MODFLOW code is used to simulate the flow in aquifers numerically.

Some field studies have been performed by Marti and Garrigues [10] to determine the physical and chemical relationships of the Spokane coupled system; they establish that river and aquifer relationship is of complex nature and that its understanding implies the hydrological analysis and the determination of the chemical variations of the systems. They have also found out that in some areas the aquifer contributes with water and in others it drains the river flow in a nonpermanent regime and that the concentrations of dissolved metals (cadmium, lead, and zinc) entering to the aquifer become diluted with the distance to the river.

A mathematical model has been developed by Workman et al. [11] to simulate the interaction of coupled systems by assuming the free river surface in an aquifer as the only hydrological stress factor; their conceptual model is one-dimensional perpendicular to the river direction and is based 
on the linear version of Boussinesq's equation and Dupuit's hypothesis. With the principle of superposition and concepts of semi-groups, their solution is of semi-analytical type using finite differences in space and time. Their results are compared with those of Serrano [12] for the solution of Laplace's stationary equation subjected to free boundary conditions and nonlinear Boussinesq's equation. Their model is tested using piezometric records of the alluvial aquifer associated with the Scioto River, located at the south central part of Ohio. On the other hand, Serrano and Workman [13] establish a model similar to Workman et al. [11], based on the nonlinear version of Boussinesq's equation and Dupuit's hypothesis; their numerical solution is derived using the decomposition method of Adomian [14]. Their model is applied in two cases of lateral flow: first using the data observed at the alluvial aquifer associated with the Scioto River and also the model is applied to a hypothetical situation of drainage toward a channel of a shallow aquifer.

Osman and Bruen [15] study the scenario of flow in which the rivers partially penetrate free alluvial aquifers, special attention is paid to cases in which the piezometric level falls below the river bed elevation. They assume the existence of three types of flow in the stream-aquifer relationship: the flow corresponding to the free river surface, the saturated flow in the aquifer, and the non-saturated flow in the vadose zone. Osman and Bruen [15] after analyzing a two-dimensional conceptual model in the vertical, based on a physical model of Bear et al. [16], proposed a correction factor for the flow exchange derived from the interaction of the three types referred above. Their implementation is in MODFLOW and validates their results against those of the SWMS-2D model for variable saturation strata using field information.

A sensitivity analysis is performed in Bruen and Osman [17] for the flow exchange and connection between rivers and aquifers with respect to the spatial variation of the saturated hydraulic conductivity using a Monte Carlo technique, and a conceptual model similar to a previously developed model in Osman and Bruen [15], with SWMS-2D code show that the correlation of parameters and degree of heterogeneity significantly affect the flow exchange, piezometric level and connection between streams and aquifers.

From the perspective of water resources in Cruickshank [18], the relationship of superficial and underground flow in basins are analyzed highlighting situations in which water is transferred from one to other medium, such as for springs and vanishing streams. He provides different exchange models as well as three specific cases to evaluate the availability and sustainability of water using numerical simulation. Mention should be made about the generalization of Bouwer [19] model. In Cruickshank [20], an alternative approximation to a previously proposed in Osman and Bruen [15] to estimate the flow exchange in streams and aquifers is presented, based on the model of Bouwer [19] for saturated flow; the Cruickshank's approximation depends on measurable characteristics such as width of the channel, geometry of the aquifer, permeability and anisotropy of the medium.

Llanusa and Martínez [21] show a procedure for the numerical simulation of the interaction between reservoirs or lakes and aquifers; their conceptual model handles explicitly the coupled balance equations of the systems being considered, their numerical solution is of finite element type for the aquifer and of predictor-corrector of second order for the reservoir.

The design and operation of effective recharge systems depend on the knowledge of the magnitude of interaction between the superficial and underground waters, Fox [22], which in turn is used to estimate the hydraulic conductivity of the river bed. He investigated analytical solutions for the determination of conductivity and suggested a synthetic simulation between rivers and aquifers to determine the magnitude of the interaction between the systems; in agreement with Osman and Bruen [15] he acknowledged that sediment, alluvium, clay deposits, and organic material deposited at the bottom decrease the conductivity of river beds in comparison with the ratio existing at the underlying aquifers. 
Barlow and Dickerman [23] mention that extraction of groundwater for public supply reduces its availability in superficial flows and affects the aquatic habitat at the surface; to be able to determine planning of the use of water at the Rhode Island Basin, they resort to a balance in the extraction of underground water, with respect to the superficial flow. Analysis of scenarios of coupled stream-aquifer systems with the purpose of determining sufficient base flows in the river are made in Fleckenstein et al. [24]. Using numerical models of groundwater flow and channels, they determine the net recharges necessary to re-establish perennial base flows in the Cosumnes River of Sacramento, California.

\section{CONCEPTUAL MODEL AND BALANCE EQUATIONS}

The equations governing the behavior of coupled river and aquifer systems are the mass and energy balance relationships for each individual system, constitutive relations and coupling terms, as well as their respective compatible boundary and initial conditions. The Saint-Venant's equations are of hyperbolic type and describe the flow in shallows channels and rivers, if mass and momentum balance in the longitudinal flow is performed, Courant-Lax [25] and Halcrow [8], then it follows:

$$
\begin{aligned}
& \frac{\partial Q}{\partial x}+\frac{\partial A}{\partial t}=q \\
& \frac{\partial Q}{\partial t}+\frac{\partial}{\partial x}\left(\beta \frac{Q^{2}}{A}\right)+g A\left(\frac{\partial H}{\partial x}-S_{f}\right)=0 .
\end{aligned}
$$

where $Q$ is the stream flow rate $\left(\mathrm{L}^{3} / \mathrm{T}\right) ; A$ is the hydraulic flow area $\left(\mathrm{L}^{2}\right) ; q$ is the inflow or outflow rate per unit length ( $\left.\mathrm{L}^{3} / \mathrm{T} / \mathrm{L}\right) ; S_{f}=Q|Q| / K^{2}$ the frictional slope (.), $K^{2}=A^{2} R^{4 / 3} / n^{2}$ and $R=A / P$, $K$ is the channel conveyance $\left(\mathrm{L}^{3} / \mathrm{T}\right), R$ is the hydraulic radius $(\mathrm{L}), P$ is the wetted perimeter $(\mathrm{L})$ and the Manning roughness coefficient $\left(\mathrm{T} / \mathrm{L}^{1 / 3}\right) ; H$ is the free surface elevation $(\mathrm{L}) ; \beta$ the momentum distribution coefficient (.); and $g$ the acceleration of gravity $\left(\mathrm{L} / \mathrm{T}^{2}\right)$. The first relation represents the mass balance and the second the momentum balance, both in the direction of river flow. If flow is subcritical, any disturbance propagates in both directions; if it is supercritical, they only propagate in downstream direction. In subcritical situation, an independent boundary condition is required upstream and other in the downstream direction, whereas for supercritical situations two independent upstream boundary conditions are necessary.

The groundwater flow is governed by the mass balance and Darcy's law, the balance equation is of elliptical type and is described in Bear [26] and Freeze-Cherry [27] as follows:

$$
\frac{\partial}{\partial x}\left(K_{x} \frac{\partial h}{\partial x}\right)+\frac{\partial}{\partial y}\left(K_{y} \frac{\partial h}{\partial y}\right)+\frac{\partial}{\partial z}\left(K_{z} \frac{\partial h}{\partial z}\right)-Q_{s}=S_{s} \frac{\partial h}{\partial t} .
$$

where $h$ is the piezometric level (L); $K_{x}, K_{y}$ and $K_{z}$ are the hydraulic conductivity in the principal axes $(\mathrm{L} / \mathrm{T}) ; Q_{s}$ is the volumetric flow per unit of volume of water sources and sinks $\left(\mathrm{T}^{-1}\right)$; and $S_{s}$ is the specific storage $\left(\mathrm{L}^{-1}\right)$. Possible boundary conditions are of Dirichlet or specified head type, and Neumann or prescribed flow; one additional possibility refers to mixed conditions, where the head maintains a functional relationship with the flow.

From the physical and mathematical point of view, to analyze the joint performance of the system, it will be necessary to establish the coupling relationships. As is indicated in Cruickshank [18], it is possible to develop different interaction models to describe the river and aquifer relationships; the variable of interest for purposes of this paper is the water exchange between both systems. Depending 
on the difference between water levels in rivers and aquifers, a flow exchange will be carried out with a trend toward the equilibrium. The simplest interchange model is described by the following relationship:

$$
Q I= \begin{cases}C(H-h) & \text { if } h>L \\ C(H-L) & \text { if } h \leq L\end{cases}
$$

where $Q I$ represents the flow between the river and the aquifer $\left(\mathrm{L}^{3} / \mathrm{T}\right)$, positive if goes to the aquifer; $H$ is the free surface elevation in the river; $h$ the piezometric level in the aquifer, referenced to the same datum than $H ; C$ and $L$ and are the conductance $\left(\mathrm{L}^{2} / \mathrm{T}\right)$ and elevation of the river bed $(\mathrm{L})$, McDonald and Harbaugh [28]. If reliable field data for the water level drawdown with the extraction flow rate are available, it would be possible to express the conductance of the river bed; otherwise, reasonable values of similar stream beds should be selected and subsequently calibrated during the model development. The first relationship is valid for an interaction range higher than $L(h>L)$; however, if the level in the aquifer $h$ becomes lower or equal to $L$, then the flow from the river becomes constant.

The proposed conceptual model for river and aquifer coupled systems, as the shown in Fig. 1, consists of the mass and momentum balance eqn (1) for rivers and for aquifers eqn (2) coupled by a flow exchange model eqn (3). The initial and boundary conditions of the balance relationships of the system eqns (1) and (2) play an important role in the performance of the system as a whole, these must be physically and mathematically compatible because they are further coupled during an iterative process; the performance of the system is dependent of its conditions. It can be stated that the model is satisfactory if the iterative coupling process and the models converge separately. The iterative process and the models numerically converge if solutions satisfy a small tolerance between two successive steps, Anderson-Woessner [29]. From the nature of the numerical procedures, the convergence means that two successive steps satisfy the necessary Cauchy conditions. Before the iterative coupling, it is necessary to have available calibrated models of rivers and aquifers, an algorithm for the coupling is described as follow:

i. Solve the river model eqns (1);

ii. Prescribe the calculated river water elevations in the flow exchange model eqn (3);

iii. Run the aquifer-related model eqn (2), which includes the exchange model eqn (3); and

iv. If water elevations and exchange flow rates fail to converge, go back to the first step and prescribe the calculated exchange flow rates in the river model eqns (1).

The election of time steps $t_{m}$ for aquifers and for $\tau_{\mu}$ for rivers in transient situations depend on the conductance of the river bed, hydraulic conductivity, porosity and aquifer storage capacity, magnitude of the water exchange between both systems, and distance of wells to river. In the present case, the same time steps was assumed for both the river and the aquifers because the materials constituting the river banks of the Papagayo River have a large porosity, conductance and hydraulic conductivity; aquifers lie at shallow depths and have a small extension and in addition wells are around $10 \mathrm{~m}$ from the river margin, therefore the interaction between the superficial and ground water is direct and quick.

For the case study, MODFLOW [28] and ISIS [8] codes were used. The approach presented here, although similar to that proposed in Swain and Wexler [4], is independent and different because in this case the ISIS program is used to simulate the mass and momentum balance in the river and because there is no redundant calculation of the flow exchange between the systems under consideration. The conceptual model in Niazi [3] is also similar to that presented here, but Niazi simplifies the equations of Saint-Venant in the kinematic model. More restrictive models exist than that 


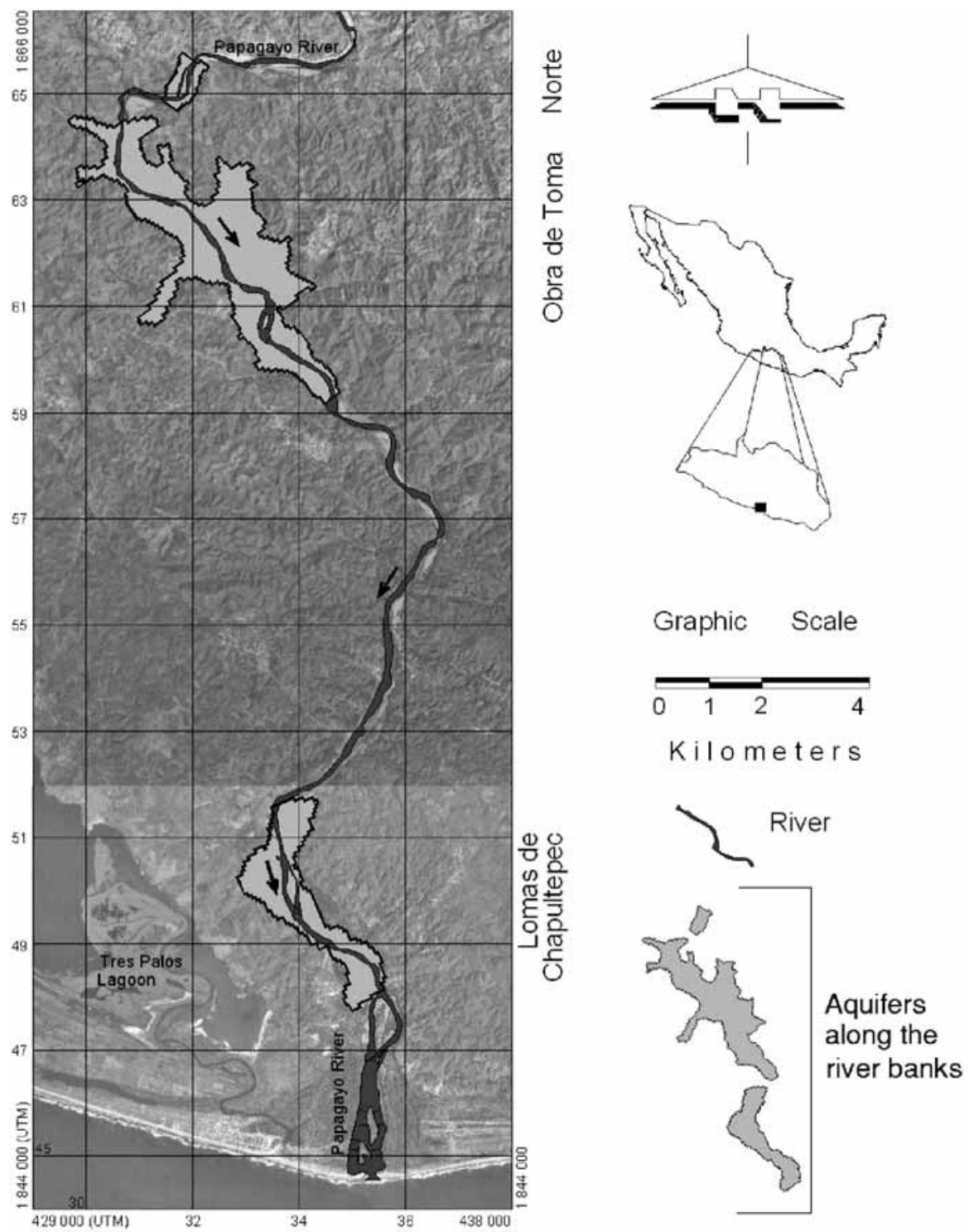

Figure 1: Site location. Papagayo river and Norte, Obra de Toma and Lomas de Chapultepec aquifer river banks.

presented in Niazi [3], Workman and Serrano [11], because his conceptual model is one-dimensional, which assume that the only acting hydrological stress is the variation of the stream level in an aquifer. The physical interchange model of Bear et al. [16] is used in Osman and Bruen [15] to obtain a correction for the flow exchange between rivers and aquifers; the resultant model is validated with field data. Sensitivity analyses were carried out in Bruen and Osman [17], for the flow exchange in previously developed models in Osman and Bruen [15]. Some exchange models are presented in Cruickshank [18] to evaluate the availability of water. Other studies analyses the interaction between aquifers and dams of lakes Llanusa and Martínez [21], and Martínez-Nájera et al. [30]. 
In this work, no simplifications are imposed in the balance eqns (1) to (3) for rivers, aquifers, and exchange model. Although the proposed interchange model is simple, it is possible to substitute it by more sophisticated exchange models as in Cruickshank [18] and Bear et al. [16] without changing the proposed conceptual approximation. There are also no restrictions imposed on the geometry, parameter distribution, and boundary and initial conditions of the hydrological systems being studied. The approach focuses wide, and naturally the simultaneous flow in rivers and aquifers, and it becomes applicable for realistic predictions and evaluations of water supply systems, MartínezNájera and Berezowsky [31]. Nevertheless, the aspects of the strong and weak analysis are pending of the existence, uniqueness and convergence of the coupled model.

Due to the difference in residence time of water in rivers and aquifers, it is necessary to analyze the effect of the magnitude of the time elapsed in the numerical simulation of coupled systems, Niazi [3] and Cruickshank [18]. For the kinematic wave model, Niazi [3] finds out that fluctuations in both the river and aquifer heads decrease with an increasing in time step and assumes that larger time steps average peak discharges, and by Manning's equation the river hydraulic heads. Also if river head is the driving force for changes in the aquifer in the vicinity of the river, then reductions in the variability of the river heads produce smaller head changes in the aquifer.

\section{NUMERICAL SOLUTION OF BALANCE EQUATIONS}

The Saint-Venant's equations are numerically solved using the Preissmann four-point implicit finite difference scheme for $H$ and $Q$, Preissmann [32], where the following approximations are used,

$$
\begin{aligned}
& f(x, t)=\left[\theta\left(f_{i+1}^{\mu+1}+f_{i}^{\mu+1}\right)+(1-\theta)\left(f_{i+1}^{\mu}+f_{i}^{\mu}\right)\right] / 2 \\
& \frac{\partial f}{\partial x}=\left[\theta\left(f_{i+1}^{\mu+1}-f_{i}^{\mu+1}\right)+(1-\theta)\left(f_{i+1}^{\mu}-f_{i}^{\mu}\right)\right] / 2 \Delta x \\
& \frac{\partial f}{\partial t}=\left[\left(f_{i+1}^{\mu+1}-f_{i+1}^{\mu}\right)+\left(f_{i}^{\mu+1}-f_{i}^{\mu}\right)\right] / 2 \Delta t
\end{aligned}
$$

where $(i, i+1)$ and $(\mu, \mu+1)$ are the spatial and temporal partition intervals with lengths of $\Delta x$ of and $\Delta \tau$, respectively, the weighting factor is in the range $0.5 \leq \theta \leq 1$, Halcrow [8]; substituting the previous equations in the river model eqn (1), the discrete mass and momentum balance equations are

$$
\left\{\begin{array}{c}
\theta\left(Q_{i+1}^{\mu+1}-Q_{i}^{\mu+1}-2 \Delta x \bar{q}_{i}^{\mu+1}\right)+(1-\theta)\left(Q_{i+1}^{\mu}-Q_{i}^{\mu}-2 \Delta x \bar{q}_{i}^{\mu}\right)+\left(A_{i+1}^{\mu+1}-A_{i+1}^{\mu}+A_{i}^{\mu+1}-A_{i}^{\mu}\right) \Delta x / \Delta \tau=0 \\
\frac{\Delta x}{\Delta \tau}\left[Q_{i+1}^{\mu+1}-Q_{i+1}^{\mu}+Q_{i}^{\mu+1}-Q_{i}^{\mu}\right]+\theta\left[\left(\beta \frac{Q^{2}}{A}\right)_{i+1}^{\mu+1}-\left(\beta \frac{Q^{2}}{A}\right)_{i}^{\mu+1}+g \bar{A}_{i}^{\mu+1}\left(H_{i+1}^{\mu+1}-H_{i}^{\mu+1}-2 \Delta x \bar{S}_{f i}^{\mu+1}\right)\right]+ \\
(1-\theta)\left[\left(\beta \frac{Q^{2}}{A}\right)_{i+1}^{\mu}-\left(\beta \frac{Q^{2}}{A}\right)_{i}^{\mu}+g \bar{A}_{i}^{\mu}\left(H_{i+1}^{\mu}-H_{i}^{\mu}\right)-2 \Delta x \bar{S}_{f i}^{\mu}\right]=0 \\
\text { for } 0<i<I \text { and } 0 \leq \mu \leq M,
\end{array}\right.
$$

where $\overline{q_{i}}=\left(q_{i+1}+q_{i}\right) / 2$ is the average of inflow per unit length, $\overline{A_{i}}=\left(A_{i+1}+A_{i}\right) / 2$ the average of flow area, and $\bar{S}_{f i}=\left(S_{f i+1}+S_{f i}\right) / 2$ the average friction slope; $\left(Q_{i}^{\mu}, H_{i}^{\mu}, q_{i}^{\mu}, \beta_{i}^{\mu}, A_{i}^{\mu}, S_{f i}^{\mu}\right)$ are the values of variables at spatial and temporal nodes $i$ and $\mu$, respectively. The equations are nonlinear 
in $\left(H_{i}^{\mu+1}, Q_{i}^{\mu+1}, H_{i+1}^{\mu+1}, Q_{i+1}^{\mu+1}, H_{i}^{\mu}, Q_{i}^{\mu}, H_{i+1}^{\mu}, Q_{i+1}^{\mu}\right)$, all terms with superscript $\mu$ are known from initial or a previous time, extreme spatial nodes are specified as boundary conditions for $H$ and/or $Q$, Fread [33] and Chau [34]; the solution of the nonlinear system means to obtain $\left(H_{i}^{\mu+1}, Q_{i}^{\mu+1}, H_{i+1}^{\mu+1}, Q_{i+1}^{\mu+1}\right)$ from $\left(H_{i}^{\mu}, Q_{i}^{\mu}, H_{i+1}^{\mu}, Q_{i+1}^{\mu}\right)$.

The $2 I$ by $2 I$ nonlinear system for mass $f_{i}^{M}\left(H_{i}^{\mu+1}, Q_{i}^{\mu+1}, H_{i+1}^{\mu+1}, Q_{i+1}^{\mu+1}\right)=0$ and momentum $f_{i}^{m}\left(H_{i}^{\mu+1}, Q_{i}^{\mu+1}, H_{i+1}^{\mu+1}, Q_{i+1}^{\mu+1}\right)=0$ for $i=1, \ldots, I-1$, eqns (4), respectively, plus boundary conditions $B C_{i}$, for $i=0$ and $i=I$ is solved by functional iterative procedures as Newton-Raphson method. The functions $f_{i}^{M}$ and $f_{i}^{m}$ goes from $\mathfrak{R}^{I-1}$ to $\mathfrak{R}$, that is $f_{i}^{M}, f_{i}^{m}: \mathfrak{R}^{I-1} \rightarrow \mathfrak{R}$, if it is defined the function $\mathbf{f}$ as $\mathbf{f}\left(\mathbf{x}^{\mu+1}\right)=\left(B C_{0}, f_{1}^{M}\left(\mathbf{x}^{\mu+1}\right), f_{1}^{m}\left(\mathbf{x}^{\mu+1}\right), \ldots, f_{I-1}^{M}\left(\mathbf{x}^{\mu+1}\right), f_{I-1}^{m}\left(\mathbf{x}^{\mu+1}\right), B C_{I}\right)^{t}$, where $\mathbf{x}^{\mu+1}=\left(H_{0}^{\mu+1}, Q_{0}^{\mu+1}, H_{1}^{\mu+1}, Q_{1}^{\mu+1}, \ldots, H_{I-1}^{\mu+1}, Q_{I-1}^{\mu+1}, H_{1}^{\mu+1}, Q_{1}^{\mu+1}\right) \in \mathfrak{R}^{2 I}$, then $\mathbf{f}$ goes from $\mathfrak{R}^{2 I}$ to $\mathfrak{R}^{2 I}$, $\mathbf{f}=B C_{0} \oplus f_{i}^{M} \oplus f_{i}^{m} \oplus B C_{I}: \Re^{2 I} \rightarrow \mathfrak{R}^{2 I}, i=1, \ldots, I-1$ then the Newton-Raphson procedure transform the nonlinear system (4) to a iterative form in $p, \mathbf{x}_{p}^{\mu+1}=\mathbf{x}_{p-1}^{\mu+1}-\mathbf{J}\left(\mathbf{x}_{p-1}^{\mu+1}\right)^{-1} \mathbf{f}\left(\mathbf{x}_{p-1}^{\mu+1}\right)$, where $\mathbf{J}\left(\mathbf{x}^{\mu+1}\right)$ is the Jacobian matrix of $\mathbf{f}\left(\mathbf{x}^{\mu+1}\right), \mathbf{J}^{-1}: \mathfrak{R}^{2 I} \rightarrow \mathfrak{R}^{2 I}$; the resulting coefficient matrix system have a banded penta diagonal structure, which can be solved by a compact Gaussian algorithm, Fread [33].

By other hand, using a block-centered grid system and backward finite difference in time, the weak aquifer flow eqn (2) is given as in McDonald and Harbaugh [28],

$$
\left\{\begin{array}{r}
C C_{i-1 / 2, j, k} h_{i-1, j, k}^{m}+C R_{i, j-1 / 2, k} h_{i, j-1, k}^{m}+C V_{i, j, k-1 / 2} h_{i, j, k-1}^{m}-\left[C C_{i-1 / 2, j, k}+C C_{i+1 / 2, j, k}+C R_{i, j-1 / 2, k}+\right. \\
\left.C R_{i, j+1 / 2, k}+C V_{i, j, k-1 / 2}+C V_{i, j, k+1 / 2}+H C O F_{i, j, k}\right] h_{i, j, k}^{m}+C C_{i+1 / 2, j, k} h_{i+1, j, k}^{m}+C R_{i, j+1 / 2, k} h_{i, j+1, k}^{m}+ \\
C V_{i, j, k+1 / 2} h_{i, j, k+1}^{m}=R_{i, j, k}-S C_{i, j, k} h_{i, j, k}^{m-1} /\left(t_{m}-t_{m-1}\right) \\
\quad \text { for } 0 \leq i \leq N R O W, 0 \leq j \leq N C O L, 0 \leq k \leq N L A Y \text { and } 0 \leq m<T
\end{array}\right.
$$

where $H C O F_{i, j, k}=P_{i, j, k}-S C_{i, j, k} /\left(t_{m}-t_{m-1}\right)$, and $S C_{i, j, k}=S S_{i, j, k} \Delta c_{i} \Delta r_{j} \Delta v_{k} ; P_{i, j, k}$ are flow interchange for cell $i, j, k$ at time $m$ in linear relationship with head, while $R_{i, j, k}$ are independent of head. $h_{i, j, k}^{m}$ is the piezometric level at node $i, j, k$ at $m$ time step; NROW indicates the number of rows, NCOL the number of columns and $N L A Y$ the number of layers, this induces a system of $N R O W^{*} N C O L^{*} N L A Y$ by $N R O W^{*} N C O L^{*} N L A Y ; C R_{i, j-1 / 2, k}=K R_{i, j-1 / 2, k} \Delta c_{i} \Delta v_{k} / \Delta r_{j-1 / 2}$ is the conductance in row $i$ and layer $k$ between nodes $i, j-1, k$ and $i, j, k$, similarly for $C C$ and $C V$ terms; $K R_{i, j-1 / 2, k}$ hydraulic conductivity along the row between nodes $i, j-1, k$ and $i, j, k ; \Delta c_{i}$ is the dimension of cell along the column direction, $\Delta r_{j}$ dimension along the row direction, and $\Delta v_{k}$ dimension of cell along the layer direction; $\Delta c_{i} \Delta v_{k}$ is the area of the cell faces normal to the row direction, similarly for orthogonal directions; $\Delta r_{j-1 / 2}$ is the distance between nodes $i, j-1, k$ and $i, j, k$, similarly for $\Delta c_{j-1 / 2}$ and $\Delta v_{j-1 / 2}$ terms; $\Delta r_{j} \Delta-$ $c_{i} \Delta v_{k}$ is the volume of cell $i, j, k ; S S_{i, j, k}$ represents the specific storage of cell $i, j, k$. The process induce the system $\mathbf{h}^{m}=\mathbf{A}^{-1} \mathbf{h}^{m-1}$ for each time step $m$, the nonzero elements of matrix $\mathbf{A}$ are located on seven diagonals located at the principal diagonal and around it, also in the diagonals NCOL and $N C O L * N R O W$, the system can be solved by Strongly Implicit Procedure, McDonald and Harbaugh [28]; the equations are linear in $\mathbf{h}$, terms with superscript $m-1$ are known from initial conditions or from a previous solution.

The discrete form of the exchange model eqn (3) can be written as

$$
Q I_{i, j, k} \begin{cases}C_{i, j, k}\left(H_{i, j, k}-h_{i, j, k}\right) & \text { if } h_{i, j, k}>L_{i, j, k} \\ C_{i, j, k}\left(H_{i, j, k}-L_{i, j, k}\right) & \text { if } h_{i, j, k} \leq L_{i, j, k}\end{cases}
$$

where $\left(Q I_{i, j, k} H_{i, j, k} C_{i, j, k}, L_{i, j, k}\right)$ are the values of variables and $h_{i, j, k}$ the piezometric level at cell $i, j, k$. 
The coupling algorithm occurs in the following way. In the steady-state case the Newton-Raphson procedure gives the solution for the river model eqns (4) by iteration in $p, \mathbf{x}_{p}=\mathbf{x}_{p-1}-\mathbf{J}\left(\mathbf{x}_{p-1}\right)^{-1} \mathbf{F}\left(\mathbf{x}_{p-1}\right)$, for $\mathbf{x}=\left(H_{0}, Q_{0}, H_{1}, Q_{1}, \ldots, H_{\mathrm{I}-1}, Q_{\mathrm{I}-1}, H_{\mathrm{I}}, Q_{\mathrm{I}}\right)$ when time derivatives vanishes in model in eqns (1). The calculated elevations for the river water levels $\left(H_{0}, H_{1}, \ldots, H_{\mathrm{I}-1}, H_{\mathrm{I}}\right)$ are prescribed in the flow exchange model in cells where the river reaches the aquifer domain as $H_{i, j, k}$, eqn (6); next run the aquifer model eqns (5), which includes the exchange model in eqn (6), then it is necessary to check if water elevations and exchange flow rates becomes stationary, if not go back and prescribe the calculated exchange flow rates $Q I_{i, j, k}$ with eqn (6) and run the river model in eqns (4) again. Similarly, for transient case for each time step from $\tau_{\mu}$ to $\tau_{\mu+1}$ the Newton-Raphson procedure gives the solution of system of eqns (4) as the asymptotic value of the iteration in $p, \mathbf{x}_{p}^{\mu+1}=\mathbf{x}_{p-1}^{\mu+1}-\mathbf{J}\left(\mathbf{x}_{p-1}^{\mu+1}\right)^{-1} \mathbf{F}\left(\mathbf{x}_{p-1}^{\mu+1}\right)$, for $\mathbf{x}_{A}^{\mu+1}=\left(H_{0}^{\mu+1}, Q_{0}^{\mu+1}, H_{A, 1}^{\mu+1}, Q_{A, 1}^{\mu+1}, \ldots, H_{A, I-1}^{\mu+1}, Q_{A, I-1}^{\mu+1}, H_{I}^{\mu+1}, Q_{I}^{\mu+1}\right), 0 \leq \mu<M$. Then the time series for water levels in river $\left(H_{0}^{\mu}, H_{1}^{\mu}, \ldots, H_{I-1}^{\mu}, H_{I}^{\mu}\right)_{\mu=0}^{\mu=M}$ is prescribed in model exchange eqn (6) in the river reach cells as $\left(H_{i, j, k}^{\mu}\right)_{\mu=0}^{\mu=M}$, and then run aquifer model eqns (5), the procedure should be stop if water elevations and flow exchange rates becomes stationary, if not go back and prescribe the calculated exchange flow rates $\left(Q I_{i, j, k}^{\mu}\right)_{\mu=0}^{\mu=M}$ with eqn (6) in the river model and run it again, eqns (4). In stationary and transient cases, the $Q I_{i, j, k}$ coupling term in eqn (6) must be identified with the average flow rate per unit length $\bar{q}_{i}$ in eqns (4) and the part in relationship with head of $H C O F_{i, j, k}$, that is, $P_{i, j, k}$ in eqn (5).

\section{STUDY CASE}

The case study corresponds to the Papagayo River and its associated aquifers located at the river banks locally identified as Norte, Obra de Toma and Lomas de Chapultepec, in the State of Guerrero, México, Fig. 1. The evaluation of sustainability of the supply system was performed by Comisión Federal de Electricidad (CFE) on request from Comisión Nacional del Agua (CNA), as an initiative for the updating and construction of water exploitation works in river banks, located downstream from La Venta or General Ambrosio Figueroa dam that operates the namesake hydroelectric power plant owned by CFE. At Obra de Toma river bank, there exists a catchment work that extracts water directly from the river, to supply at a rate of about $1.5 \mathrm{~m}^{3} / \mathrm{s}$; however, this structure developed continuous silting problems. In the same river bank, there are also several shallow wells with a combined flow rate of $0.67 \mathrm{~m}^{3} / \mathrm{s}$, as well as a Ranney well $4 \mathrm{~m}$ in diameter that extracts between 0.25 and 0.50 $\mathrm{m}^{3} / \mathrm{s}$, and a radial well of similar diameter that yields from 0.50 to $0.75 \mathrm{~m}^{3} / \mathrm{s}$; the location of the exploitation works are shown in Fig. 2, as well as the initial piezometric configuration in the Obra de Toma aquifer river bank, after the calibration process, which is discussed in next sections. Indirectly, the wells pump the water from the river, eqn (3), using the river banks as natural filters, therefore, minimizing maintenance of the pumping and conveyance equipment. At the Norte and Lomas de Chapultepec river banks, there are no, at present, exploitation works for supply purposes. The conceptual approximation is applied to determine the sustainable limits of the river's direct contribution and through the aquifers in river banks, taking into account the current extraction rates as well as the hydrometric and morphologic aspects of the river and the hydrological characteristics of the associated river banks.

\section{CONCEPTUAL HYDROGEOLOGIC MODEL}

The studies were carried out by CNA [35] and [36]; CFE [37, 38] and [5] showed that the aquifers in river banks were constituted by alluvial deposits and terraces with high permeability and storage potential. Recharging of each aquifer comes exclusively from the river, aquifers and river beds are underlain by the Xolapa metamorphic complex that evidence dense constitution and low fracturing and is considered to have a very low permeability and almost inexistent lateral recharges 


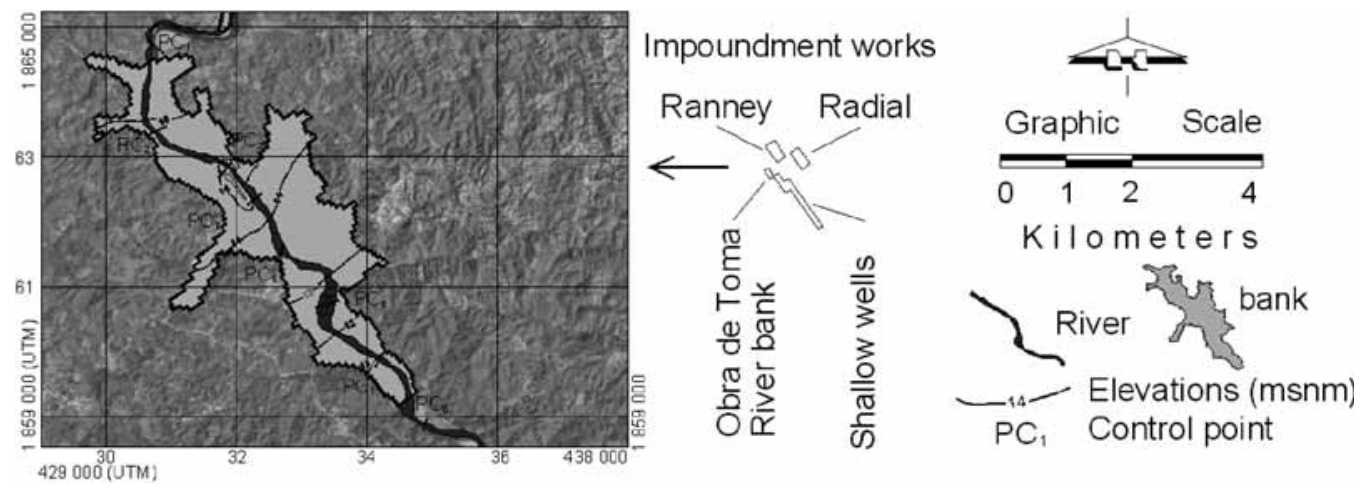

Figure 2: Piezometric configuration calibrated at the beginning of the pulse through the northern boundary (msnm) at Obra de Toma aquifer river bank. Impoundment works and location of topobathymetric cross sections and of control points $\mathrm{PC}_{1}-\mathrm{PC}_{8}$.

Table 1: Minimum monthly discharges $\left(\mathrm{m}^{3} / \mathrm{s}\right)$.

\begin{tabular}{lccc}
\hline \multirow{2}{*}{ Month } & \multicolumn{3}{c}{ Hydrometric Station } \\
\cline { 2 - 4 } & El Puente & Agua Salada & La Parota \\
\hline January & 20.80 & 6.97 & 25.39 \\
February & 18.53 & 5.32 & 21.69 \\
March & 14.32 & 4.08 & 17.26 \\
April & 13.10 & 3.01 & 14.12 \\
May & 12.64 & 2.35 & 14.21 \\
June & 21.95 & 11.84 & 36.33 \\
July & 50.65 & 28.33 & 79.85 \\
August & 59.32 & 34.07 & 91.75 \\
September & 88.06 & 64.12 & 149.37 \\
October & 86.22 & 38.25 & 124.60 \\
November & 41.40 & 16.62 & 56.51 \\
December & 28.24 & 8.55 & 35.44 \\
\hline
\end{tabular}

into the river banks. One source of minor recharge of the aquifers comes from rainfall and runoff. From the hydrometric data of the river, collected at stations La Parota (April 1962-December 1997), El Puente (January 1993-December 1997) and Agua Salada (August 1968-December 1997) minimum monthly flow rate values are obtained, Table 1 , from which it is possible to determine the minimum threshold of runoff along the river. The minimum daily flow rates can even reach $0 \mathrm{~m}^{3} / \mathrm{s}$. In the 36 years registered, this situation has been encountered only once. La Parota, El Puente, and Agua Salada stations are located more than $5 \mathrm{~km}$ north of the Obra de Toma river bank, Fig. 1. 


\section{NUMERICAL MODELS, STATIONARY AND TRANSIENT CASES}

Campaigns of hydrometric and topographic measurements were executed in field to determine hourly water elevations and geometry of the river. At the same time, field studies were carried out of geological, hydrogeological, geophysical, climatological, and topographical types to determine the geometry, parameters, hydrological stresses, and boundary conditions of the aquifers located at the river banks being studied. The two types of models were built, one for the Papagayo river and the other for each of the aquifers in river banks. Eight topobathymetric cross sections or control points labeled $\mathrm{PC}_{1}-\mathrm{PC}_{8}$, Fig. 2, were surveyed at Obra de Toma river bank for calibrating purposes.

Table 2 and Fig. 2 show fitting of the underground flow model to measured field data. The piezometric level drops similarly to the river water elevation. Figure 3 depicts fitting of the river model to

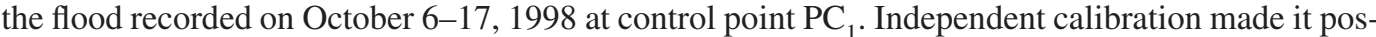
sible to determine models consistent with field observations.

Two different types of initial and boundary conditions were assumed as referred to the stationary and transient status. Boundary conditions handled by ISIS for the stationary case correspond to a constant input of flow rate through the upstream boundary located at $20 \mathrm{~km}$ north of the Obra de Toma aquifer in La Parota hydrometric station, Fig. 1, that is combined with a condition of constant water elevation at the downstream boundary located south of the Lomas de Chapultepec river bank. The configuration of startup and calibration is assumed to be equal to the distribution of water levels observed during the period of river flow measurement. On the other hand, for the boundary condition for groundwater models of the river banks, a zero flow is assumed along the periphery of them as well as a small vertical recharging rate due to precipitation, with an initial configuration equal to the variation of water levels in the river that has been obtained through the ISIS-calibrated model in the first iteration of the process. The aquifer is fed by the river according to the model in eqn (3). From model in eqn (3) it follows that rivers and streams interact with aquifers in the next ways: when $h>H$ river gains water from the aquifer through the streambed; when $h \leq H$ the river loses water to the aquifer through the streambed, this includes the case when $h \leq L$. Aquifers gain water in some river reaches and could lose in other reaches depending on the relationship between $h$ and $H$, Cruickshank [18] and Marti and Garrigues [10].

Table 2: Topobathymetric cross sections, control points and fitting of underground flow model to field data at Obra de Toma river bank; all elevations are expressed in meters above mean sea level (msnm).

\begin{tabular}{lccc}
\hline & \multicolumn{2}{c}{ Measured elevations } & Computed elevations \\
\cline { 2 - 4 } Section & River bed & Water level & Groundwater flow \\
\hline $\mathrm{PC}_{1}$ & 14.60 & 15.71 & 15.31 \\
$\mathrm{PC}_{2}$ & 13.20 & 14.64 & 14.50 \\
$\mathrm{PC}_{3}$ & 12.37 & 14.13 & 13.98 \\
$\mathrm{PC}_{4}$ & 12.20 & 14.09 & 13.80 \\
$\mathrm{PC}_{5}$ & 12.72 & 13.69 & 13.29 \\
$\mathrm{PC}_{6}$ & 11.76 & 12.40 & 12.10 \\
$\mathrm{PC}_{7}$ & 10.20 & 10.75 & 10.55 \\
$\mathrm{PC}_{8}$ & 8.96 & 10.06 & 9.86 \\
\hline
\end{tabular}




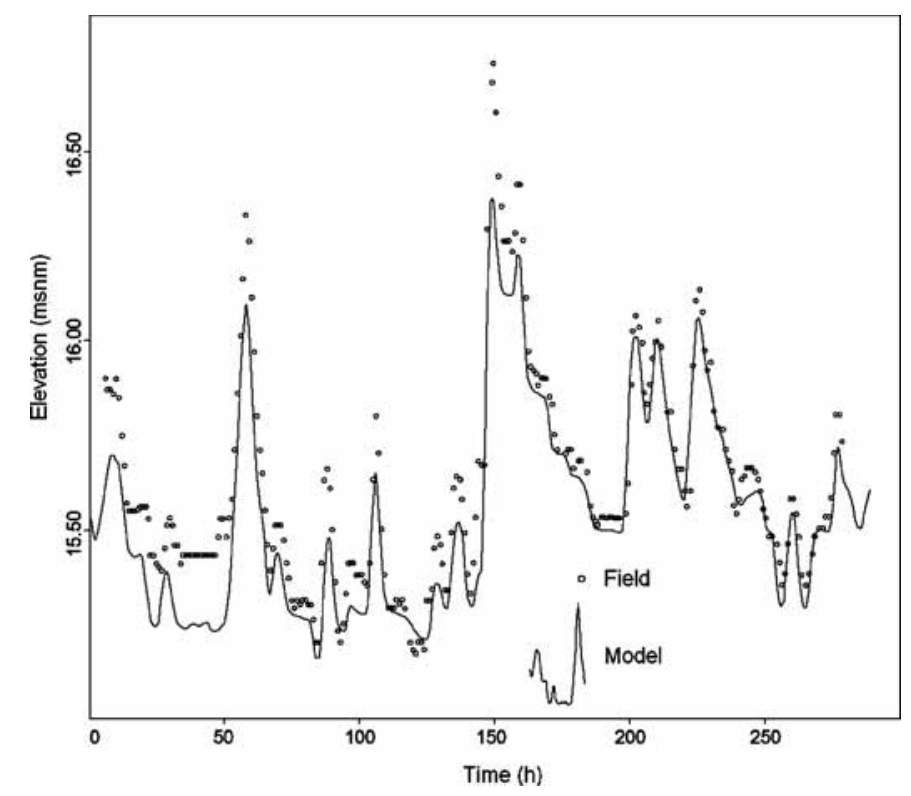

Figure 3: Computed and measured water levels for the flood recorded on October 6-17, 1998 at control point $\mathrm{PC}_{1}$.

The stationary approach makes it possible to determine the potential supply of the river through its river banks, after assuming a constant inlet rate of flow through its upstream boundary; in other words, the stationary management allows analyzing the supply thresholds of the river-aquifer coupled system. Constant inlet flow rates that are simulated in the project are equal to 20 and $4 \mathrm{~m}^{3} / \mathrm{s}$, corresponding to the range extreme discharges recorded at La Parota hydrometric station during the period from 1962 to 1998. Handling of the initial and boundary conditions of the models concerning the transient regime is similar to that applied for the stationary cases, the difference focuses on the addition of variable hydrographs at the upstream boundary of the river. In transient case, the boundary condition upstream has a variation from an initial flow rate $Q_{i}$ to a final $Q_{f}$ within a time interval $D_{t}$ (the particular case when $Q_{i} \geq Q_{f}$ makes it possible to simulate critical supply conditions); similarly to the stationary case, a constant water level condition is established at the downstream boundary, whereas for the initial condition, it is assumed the distribution of water elevations observed during the flow-measurement period of the river. The hydrograph at the upstream boundary induces a variation along its length and establishes a series of hydrologic stresses that promote the exchange of water among the river and its banks; that is, such hydrograph produces a limnigraph at each point of the river that determines the magnitude of water exchange according to the model established by eqn (3). The limnigraphs cover from an initial level $H_{i}^{p}$ to a final level $H_{f}^{p}$ within the time interval $D_{t^{*}}$, where $H_{i}^{p} \geq H_{f}^{p}$ valid for the assumption $Q_{i} \geq Q_{f}$; superscript $p$ denotes a control point along the river course. Limnigraphs are prescribed in MODFLOW to determine a series of water exchanges $Q_{r}^{p}$ among the river and aquifers in their banks in the control point $p$; finally, the series of flow rate values thus determined serves as input to ISIS to simulate an additional step in the coupling iterative process. Similarly to the stationary situation, in the MODFLOW models a zero Neumann condition through its boundary is assumed, with an initial condition equal to the variation of water elevations in the river that is obtained from ISIS during the first iteration of the process. The transient analysis enables the determination of the river and aquifers supply potential, as well as the time in which the 
system is capable of sustaining the required demand. After assuming a decrease in the inlet discharge through the northern boundary of the river, transient management makes it possible to find out the performance thresholds for supply and sustainability of the coupled system. Inlet discharges that are simulated in this project ranges from 20 to $4 \mathrm{~m}^{3} / \mathrm{s}$, the most critical case corresponds to that where the hydrograph is a pulse varying from $20 \mathrm{~m}^{3} / \mathrm{s}$ to zero within the interval time of $D_{t}$.

\section{OBTAINED RESULTS}

To be able to perform the analysis in terms of flow exchange among systems, three scenarios were handled using the eight control points, labeled $\mathrm{PC}_{1}-\mathrm{PC}_{8}$, Fig. 2 and Table 2, at the intersection of the river with the aquifer at Obra de Toma river bank. Currently no water is extracted at river banks Norte and Lomas de Chapultepec for supply purposes, the Papagayo River maintains their piezometric levels.

The first scenario contemplates a constant inlet hydrograph equal to $20 \mathrm{~m}^{3} / \mathrm{s}$ at the northern boundary of the river; while flowing through the river bank, groundwater is extracted by radial and shallow wells with a combined yield of $1.51 \mathrm{~m}^{3} / \mathrm{s}$; on the other hand, water is also extracted directly from the river at Obra de Toma facility at a rate of $1.5 \mathrm{~m}^{3} / \mathrm{s}$ and it is explicitly considered in the surface model processed with ISIS. As a result of extractions, the river discharge decreases after exiting the river bank, this characteristic is intended to be estimated and numerically simulated to determine the sustainability of the system. Table 3 shows the water elevations of the river at control points $\mathrm{PC}_{1}-\mathrm{PC}_{8}$ located at Obra de Toma river bank, as well as the volumes contributed by the river according with the numerical simulation process with MODFLOW and ISIS models. If the flow interchange is steady, the river contributes the required water of radials and shallow wells. The second scenario considers an incoming hydrograph assumed constant at the northern boundary, but here at a rate of $4 \mathrm{~m}^{3} / \mathrm{s}$. Table 4 presents the water elevations at the river control points $\mathrm{PC}_{1}-\mathrm{PC}_{8}$ together with the volumes contributed by the river during the iterative process. It can be observed in these results that after two iterations, the flow interchange reach their asymptotic value of $1.51 \mathrm{~m}^{3} / \mathrm{d}$, the joint model converges starting from the third iteration; once again the river contributes with the required sustainable flow rate. From the continuity principle and the flow interchange model, eqn (3), and after the coupling process become stationary as is indicated in Tables 3 and 4, the aquifer gain water from the river in an amount of $138,081.52 \mathrm{~m}^{3} / \mathrm{d}$, with an output to the river of $7,878.48 \mathrm{~m}^{3} / \mathrm{d}$ giving a total input balance of $130,203.04 \mathrm{~m}^{3} / \mathrm{d}\left(1.51 \mathrm{~m}^{3} / \mathrm{s}\right)$.

A variable hydrograph at the northern boundary of the river was introduced in the last scenario, with an initial flow rate of $20 \mathrm{~m}^{3} / \mathrm{s}$ that decreases to $4 \mathrm{~m}^{3} / \mathrm{s}$ in a time interval of $5 \mathrm{~h}$, therefore, inducing a corresponding evolution of water levels along the river course, particularly at Obra de Toma river bank. The variation of river water elevation is prescribed in the MODFLOW model, eqn (3), to

Table 3: First scenario. Coupling of MODFLOW and ISIS. Water elevation at control points $\mathrm{PC}_{1}-$ $\mathrm{PC}_{8}(\mathrm{msnm})$ and flow rates contributed by the river $\left(\mathrm{m}^{3} / \mathrm{s}\right)$, considering a discharge of $20 \mathrm{~m}^{3} / \mathrm{s}$ through the northern boundary.

\begin{tabular}{lccccccccc}
\hline $\mathrm{I}$ & $\mathrm{PC}_{1}$ & $\mathrm{PC}_{2}$ & $\mathrm{PC}_{3}$ & $\mathrm{PC}_{4}$ & $\mathrm{PC}_{5}$ & $\mathrm{PC}_{6}$ & $\mathrm{PC}_{7}$ & $\mathrm{PC}_{8}$ & $\begin{array}{c}\text { Flow rate } \\
\text { contributed } \\
\text { by river }\end{array}$ \\
\hline $\mathrm{I}_{0}$ & 15.71 & 14.61 & 14.00 & 13.96 & 13.69 & 12.39 & 10.75 & 9.46 & ---- \\
$\mathrm{I}_{1}$ & 15.71 & 14.61 & 13.96 & 13.92 & 13.66 & 12.38 & 10.74 & 9.45 & 1.51 \\
$\mathrm{I}_{2}$ & 15.71 & 14.61 & 13.96 & 13.92 & 13.66 & 12.38 & 10.74 & 9.45 & 1.51 \\
\hline
\end{tabular}

$\mathrm{I}_{\mathrm{i}}:$ ith iteration. $\mathrm{PC}_{\mathrm{k}}: k$ th control point. 
Table 4: Second scenario. Coupling of MODFLOW and ISIS. Water elevation at control points $\mathrm{PC}_{1}-\mathrm{PC}_{8}(\mathrm{msnm})$ and flow rates contributed by the river $\left(\mathrm{m}^{3} / \mathrm{s}\right)$, considering a discharge of $4 \mathrm{~m}^{3} / \mathrm{s}$ through the northern boundary.

\begin{tabular}{lrrrrrrrrr}
\hline $\mathrm{I}$ & $\mathrm{PC}_{1}$ & $\mathrm{PC}_{2}$ & $\mathrm{PC}_{3}$ & $\mathrm{PC}_{4}$ & $\mathrm{PC}_{5}$ & $\mathrm{PC}_{6}$ & $\mathrm{PC}_{7}$ & $\mathrm{PC}_{8}$ & $\begin{array}{c}\text { Flow rate } \\
\text { contributed } \\
\text { by river }\end{array}$ \\
\hline $\mathrm{I}_{0}$ & 15.09 & 13.73 & 13.36 & 13.35 & 13.17 & 12.03 & 10.47 & 9.19 & ---- \\
$\mathrm{I}_{1}$ & 15.09 & 13.71 & 13.18 & 13.16 & 12.92 & 11.95 & 10.42 & 9.10 & 1.34 \\
$\mathrm{I}_{2}$ & 15.09 & 13.71 & 13.25 & 13.23 & 13.00 & 11.97 & 10.44 & 9.17 & 0.96 \\
$\mathrm{I}_{3}$ & 15.09 & 13.70 & 13.18 & 13.16 & 12.87 & 11.89 & 10.37 & 9.07 & 1.51 \\
$\mathrm{I}_{4}$ & 15.09 & 13.70 & 13.18 & 13.16 & 12.87 & 11.89 & 10.37 & 9.07 & 1.51 \\
$\mathrm{I}_{5}$ & 15.09 & 13.70 & 13.18 & 13.16 & 12.87 & 11.89 & 10.37 & 9.07 & 1.51 \\
\hline
\end{tabular}

$\mathrm{I}_{\mathrm{i}}: i$ th iteration. $\mathrm{PC}_{\mathrm{k}}: k$ th control point.

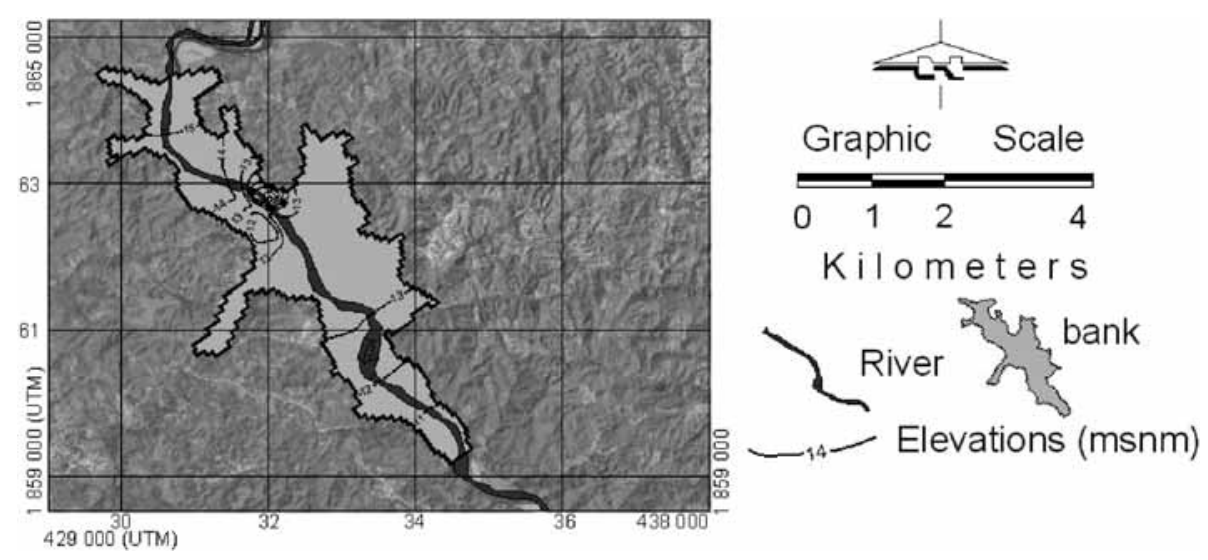

Figure 4: Piezometric configuration at Obra de Toma aquifer after 16.67 days from the beginning of the pulse at the northern boundary.

obtain the response of flow exchange; which is prescribed in ISIS to start a new iteration. Figure 4 shows the piezometric configuration in the aquifer after an elapsed time of 16.67 days following the start pulse from the northern boundary; drawdown cones can be observed around the wells. For comparison purposes, Fig. 2 depicts the initial configuration in the aquifer at Obra de Toma river bank. Figure 5 presents the transmission of level drop pulse from the northern to southern portion of the river bank. At the end of the 16.67 days, the water level becomes stationary as a $12 \mathrm{~m}$ cone approximately around the radial and shallow wells, Fig. 4; in this situation the river also yields the sustainable required discharge. In what refers to river banks Norte and Lomas de Chapultepec, and since there is no extraction from them, the piezometric level in the river banks drop proportionately to the water elevation subsidence in the river. In this case also the river contributes with the flow rate required by the wells and the catchment work that extracts water directly from the river. Once again from the continuity principle and the flow interchange model, eqn (3), after reaching steady-state, the aquifer gain water from the river, the total input to the aquifer is $136,833.24 \mathrm{~m}^{3} / \mathrm{d}$, with output to the river of $6,705.11 \mathrm{~m}^{3} / \mathrm{d}$ giving a total balance of $130,128.13 \mathrm{~m}^{3} / \mathrm{d}\left(1.51 \mathrm{~m}^{3} / \mathrm{s}\right)$. 

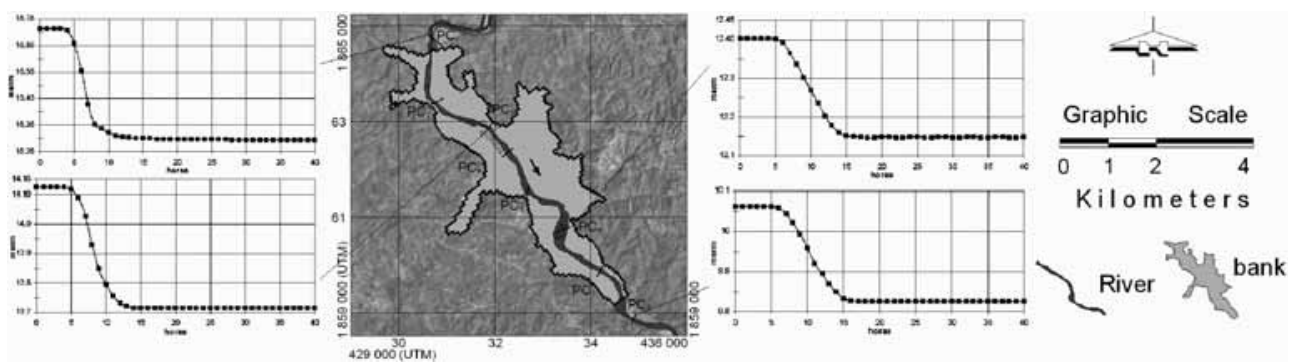

Figure 5: Transmission pulse of the level drop from the north to the south portion of Obra de Toma river bank.

\section{CONCLUSIONS}

A conceptual and mathematical approximation is presented to simulate numerically the hydrologic behavior of river and aquifer as coupled systems under natural and realistic conditions. The associated model makes it possible to analyze their response under different sustainable supply scenarios; the numerical implementation is carried out by using MODFLOW and ISIS codes. The model consists of the conceptual and numerical coupling of two structures that take into account different hydrologic aspects of the systems. The first structure considers the mass and momentum balance in the river, the second one performs the mass balance in combination with Darcy's law in each of the aquifers under study; their coupling is given in an iterative fashion.

The approximation is applied to the system constituted by the Papagayo river and the aquifers located at the Norte, Obra de Toma and Lomas de Chapultepec river banks, in the State of Guerrero, México. Two stationary cases and one of transient nature were analyzed. The stationary analysis allows the determination of supply thresholds, whereas the transient one determines the performance and time thresholds in which the system satisfies the extraction demand. In the analyzed cases, the approximation numerically proves that the river is capable of contributing with a sustainable flow rate of $1.51 \mathrm{~m}^{3} / \mathrm{s}$, required on demand by the shallow wells, Radial and Ranney wells, as well as of $1.50 \mathrm{~m}^{3} / \mathrm{s}$ from a direct pumping facility located at Obra de Toma river bank; this situation has been registered at the site; therefore the model seems to be consistent with field observations, Figs 2, 3, 4, 5 and Tables 2, 3, 4. Under the present conditions, it has been determined that river sustains the required demanded flow rate of $3.01 \mathrm{~m}^{3} / \mathrm{s}$ and that the hydrological connection between river and aquifers is strong. The conceptual and numerical model predicts the natural response of the system when it is subjected to additional extraction scenarios.

\section{ACKNOWLEDGMENTS}

The authors are indebted to the authorities of Comisión Federal de Electricidad and Comisión Nacional del Agua of México for providing the study area and the research opportunity in the site. They also acknowledge Ing. Gustatavo Arvizu Lara, Ing. Carlos Sánchez Linares and Ing. Victor Mata Villavicencio for their valuable support in the accomplishment of the project.

\section{REFERENCES}

[1] Sophocleous, M. Interactions between groundwater and surface water: the state of the science. Hydrogeology Journal, 10, pp. 52-67, 2002. doi: http://dx.doi.org/10.1007/s10040-001-0170-8

[2] Nilsson, B., Dahl, M., Langhoff, J.H., Kronvang, B., Christensen, S., Andersen, H.E., Hoffmann, C.C., Rasmussen, K.R. \& Refsgaard, J.C. Groundwater/surface water interaction - A Danish typological approach. Geophysical Research Abstracts, 6, 03280, SRef-ID 1607-7962/ gra/EGU04-A-03280, European Geosciences Union, p. 2, 2004. 
[3] Niazi, S. Sensitivity Analysis of time-step in Modeling River and Aquifer Interaction. Master of Science in Engineering Thesis, University of Texas at Austin, Austin, 190 pp., 2000.

[4] Swain, E.D. \& Wexler, E.J. A Coupled Surface-water and Ground-water Flow Model (MODBRANCH) for Simulation of Stream-aquifer Interaction. US Geological Survey, Techniques of Water-Resources Investigations, Book 6, Chapter A6, Washington, D.C., p. 125, 1996.

[5] CFE 3. Subdireccion Tecnica/GEIC/SEH/ASV de MM. Reporte de avance de la modelacion matematica del proyecto integral de abastecimiento de agua subterranea a la ciudad de Acapulco, Gro. Internal Report CFE, p. 86, 1999.

[6] Martinez-Najera, J.D., Flores-Ibarra, C. \& Olvera-Coronel, M. Quantitative evaluation of river-aquifer supply systems. 2001 Annual Conference of the International Association for Mathematical Geology, Cancun: Mexico, p. 11, 2001.

[7] Schaffranek, R.W., Baltzer, R.A. \& Goldberg, D.E. A model for simulation of flow in singular and interconnected channels. US Geological Survey, Techniques of Water-Resources Investigations, Book 7, Chapter C3, Washington, p. 110, 1981.

[8] Halcrow/ HR Wallingford. ISIS flow. User manual. Oxfordshire: UK, p. 318, 1995.

[9] Swain, E.D. Incorporating hydraulic structures in an open-channel model. Proceedings, 1992 National Hydraulic Engineering Conference, American Society of Civil Engineers, New York, NY., pp. 1118-1123, 1992.

[10] Marti, P.B. \& Garrigues, R.S. Spokane river/aquifer interaction project results, May - November 1999. Washington State Department of Ecology, Publication No. 01-03-024, p. 88, 2001.

[11] Workman, S.R., Serrano, S.E. \& Liberty, K. Development and application of an analytical model of stream/aquifer interaction. Journal of Hydrology, 200, pp. 149-163, 1997. doi: http:// dx.doi.org/10.1016/S0022-1694(97)00014-0

[12] Serrano, S.E. Analytical solutions of the nonlinear groundwater flow equation in unconfined aquifers and the effect of heterogeneity. Water Resour. Res., 31(11), pp. 2733-2742, 1995. doi: http://dx.doi.org/10.1029/95WR02038

[13] Serrano, S.E. \& Workman, S.R. Modeling transient stream/aquifer interaction with the non-linear Boussinesq equation and its analytical solution. Journal of Hydrology, 206, pp. 245-255, 1998. doi: http://dx.doi.org/10.1016/S0022-1694(98)00111-5

[14] Adomian, G. A review of the decomposition method and some recent results for nonlinear equations. Comp. Math. Applic., 21(2), pp. 101-127, 1991. doi: http://dx.doi.org/10.1016/08981221(91)90220-X

[15] Osman, Y.Z. \& Bruen, M.P. Modelling stream-aquifer seepage in an alluvial aquifer: An improved loosing-stream package for MODFLOW. Journal of Hydrology, 264, pp. 69-86, 2002. doi: http://dx.doi.org/10.1016/S0022-1694(02)00067-7

[16] Bear, J., Zaslavsky, D. \& Irmay, S. Physical principles of water percolation and seepage. UNESCO: Paris, p. 465, 1968.

[17] Bruen, M.P. \& Osman, Y.Z. Sensitivity of stream-aquifer seepage to spatial variability of the saturated hydraulic conductivity of the aquifer. Journal of Hydrology, 293, pp. 289-302, 2004. doi: http://dx.doi.org/10.1016/j.jhydrol.2004.02.003

[18] Cruickshank-Villanueva, C. Relacion entre las aguas superficiales y las subterraneas en una cuenca. Ingenieria Hidraulica en Mexico, pp. 56-63, 1992.

[19] Bouwer, H. Theory of seepage from open channels. Advances in Hydroscience, 7, ed. Ven-Te-Chow, Mc Graw Hill: New York, pp. 121-172, 1976.

[20] Cruickshank-Villanueva, C. Personal communication, May 2004. On the infiltration formulas for rivers in the numerical simulation of aquifers.

[21] Llanusa, R.H. \& Martinez-Rodriguez, J.B. Modelacion explicita de embalse y acuifero. Ingenieria Hidraulica en Mexico, XVII(4), pp. 89-97, 2002. 
[22] Fox, G. Estimating streambed and aquifer parameters from a stream/aquifer analysis test. Proceedings of the 23rd Annual Geophysical Union Hydrology Days, ed. J.A. Ramirez, Colorado State University: Fort Collins, pp. 68-79, 2003.

[23] Balancing ground-water withdrawals and streamflow in the Hunt-Annaquatucket-Pettaquamscutt basin, Rhode Island. USGS Fact Sheet FS-063-01. Barlow, P.M. \& Dickerman, D.C. On line. http://pubs.usgs.gov/fs/fs063-01/.

[24] Fleckenstein, J., Anderson, M., Fogg, G. \& Mount, J. Managing surface water-ground water to restore fall flows in the Cosumnes River. Journal of Water Resources Planning and Management, ASCE, 130(4), pp. 301-310, 2004. doi: http://dx.doi.org/10.1061/(ASCE)07339496(2004)130:4(301)

[25] Courant, R. \& Lax, P. On nonlinear partial differential equations with two independent variables. Comm. Pure Appl. Math, 2(3), pp. 255-273, 1949. doi: http://dx.doi.org/10.1002/ cpa.3160020206

[26] BEAR, J. Dynamics of Fluids in Porous Media. American Elsevier: New York, p. 764, 1972.

[27] Freeze, R.A. \& Cherry, J.A. Groundwater. Hemel Hempstead: Prentice-Hall, Inc., Englewood Cliffs, NJ., p. 604, 1979.

[28] McDonald, M.G. \& Harbaugh, A.W. A modular three-dimensional finite-difference groundwater flow model. U.S. Geological Survey, Open-File Report: Washington, p. 568, 1988.

[29] Anderson, M.P. \& Woessner, W.W. Applied Groundwater modeling. Simulation of Flow and Advective Transport. San Diego: Academic Press, p. 381, 1992.

[30] Martinez-Najera, J.D., Talamantes-Contreras, P., Sanchez-Linares, C. \& Olvera-Coronel, M. Analisis del acoplamiento y modelacion matematica de sistemas embalse y acuifero. Ingenieria Hidraulica en Mexico, XXIV(3), pp. 91-99, 2009

[31] Martinez-Najera, J.D. \& Berezowsky-Verduzco, M. Evaluacion del abastecimiento de sistemas rio-acuifero. Ingenieria Hidraulica en Mexico, XXIII(4), pp. 173-187, 2008.

[32] Preissmann, A. Propagation des intumescences dans les canaux et rivieres. ler Congres de l'Assoc. Francaise de Calcul, Grenoble, France, pp. 433-442, 1961.

[33] Fread, D.L. An implicit dynamic wave model for mixed flows in storm sewer networks. International Symposium on Urban Hydrology, Hydraulics and Sediment Control, University of Kentucky: Lexington, Kentucky, p. 17, 1985.

[34] Chau, K.W. Application of the Preissmann scheme on flood propagation in river systems in difficult terrain. Hydrology in Mountainous Regions. I - Hydrological Measurements. The Water Cycle, Proceedings of two Lausanne Symposia, IAHS Publ. 193, pp. 535-543, 1990.

[35] CNA 1. Subdireccion General Tecnica/Gerencia de Aguas Subterraneas/Subgerencia de Exploracion y Monitoreo Geohidrologico. Informe sobre el estado actual de las principales fuentes de abastecimiento de agua potable del puerto de Acapulco, Edo. de Guerrero. Internal Report CNA, September, p. 20, 1997.

[36] CNA 2. Subdireccion General Tecnica/Gerencia de Aguas Subterraneas/Subgerencia de Exploracion y Monitoreo Geohidrologico. Comentarios preliminares acerca de la construccion de pozos someros en el playon de la margen derecha del rio Papagayo, en la cercania de Aguas Calientes, Edo. de Gro. Internal Report CNA, February, p. 35, 1998.

[37] CFE 1. Subdireccion Tecnica/GEIC/SEH/DGH. Avance del estudio integral de sistemas de abastecimiento de agua subterranea a la ciudad de Acapulco, Gro. (Rios Papagayo y Coyuca). Internal Report CFE, p. 50, 1998a.

[38] CFE 2. Subdireccion Tecnica/GEIC/SEH/DGH. Estudio para la caracterizacion hidrogeologica sobre el rio Papagayo. Sitio Playon Norte. Internal Report CFE, p. 25, 1998 b. 